\title{
Message from the IFFAS President
}

\author{
Cristian Ortiz
}

Journal of Foot and Ankle Surgery (Asia Pacific) (2020): 10.5005/jp-journals-10040-1132

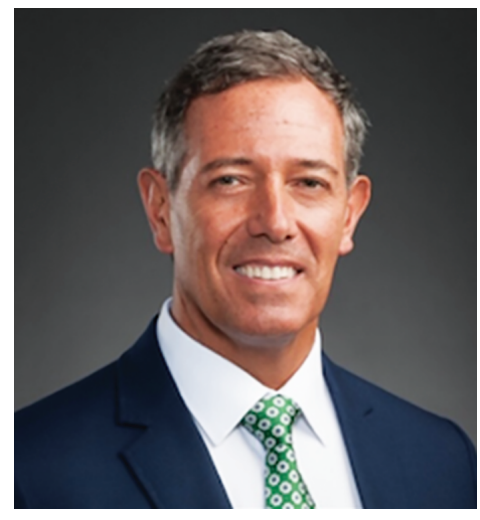

Greetings from the International Federation of Foot and ankle Surgeons (IFFAS). I am honored to be elevated to the post of the president this year, and I send greetings to all my colleagues who practice foot/ankle surgery across Asia-Pacific region.

Each one of the Pandemia's predictions has proven to be far away from what has really happened. In my small and isolated country (Chile), we have tried to learn from the experience coming from Asia and Europe. Unfortunately, in South America we are still struggling in most of our countries with what has been called the first wave. The virus has impacted not only our health status but also every aspect of our lives including our daily work. We had to cancel the 2020 IFFAS Congress that was to be held in my hometown, which was a great letdown to all concerned; https:// www.iffaschile2020.com/.

Please do visit the website above.

Spending less time in the operating room probably has a good side, but everyone has experienced this differently. More quality time with the family, understanding how vulnerable we all are, how complicated are politics and economic decisions, and how important is the way we all communicate and share experiences are what we have understood in these trying times.

Most of us have seen our places of work remain busy with increasing number of patients, but the pattern has changed, and we have been forced to cancel elective surgeries, often work only for trauma and in some places stay home in lockdowns. This special time we are going through has allowed us to think about our purpose in life, especially as doctors. We have been forced to create new ways in medical education, research, and how to practice medicine. This is even more difficult in a small community like ours, which is focused on foot and ankle. More important of all, we have formed a new way of living.

The pandemic has focused our thinking on newer patient care delivery systems, and research, and even virtual education and telecommunication, all of us give our best for our patients. For treating our patients well we always needed to be informed, updated about new knowledge, practice our skills, and never stop looking for the answers and solutions that we need. This is needed to be a good doctor, but today we are forced to use different methods that do not allow personal interaction but have to be done online virtually to update clinical practice, medical education, and research. An important case in point is the IFFAS 2020, which has now been postponed to 2021, but IFFAS continues to strive
How to cite this article: Ortiz C. Message from the IFFAS President. J Foot Ankle Surg (Asia Pacific) 2020;7(2):35-36.

Source of support: Nil

Conflict of interest: None

to spread education in the online programs it is conducting. My message to all IFFAS members worldwide is available on the website https://www.iffaschile2020.com/everyone-on-the-bus/, but I am writing to you all personally so that the Asia-Pacific region becomes more involved in IFFAS activities.

As I get older, I pay more attention to the basis of my daily practice that begins with proper information, which is provided by good medical education like this journal.

In the last few years, I have been extremely lucky to be able to travel around the world sharing my humble experience and learning how creative and talented are the colleagues who sometimes are so busy doing a great work that they just do not have time to publish their amazing experiences. In my visit to Asia, as part of the AO Foot Curriculum Development Team, and as guest faculty at the Congress of the Indian Foot and Ankle Society, in Coimbatore, I found a great diversity of data from Asia, which was presented but probably not published (here is my photo from my 2017 visit to IFASCON 2017 in South India).

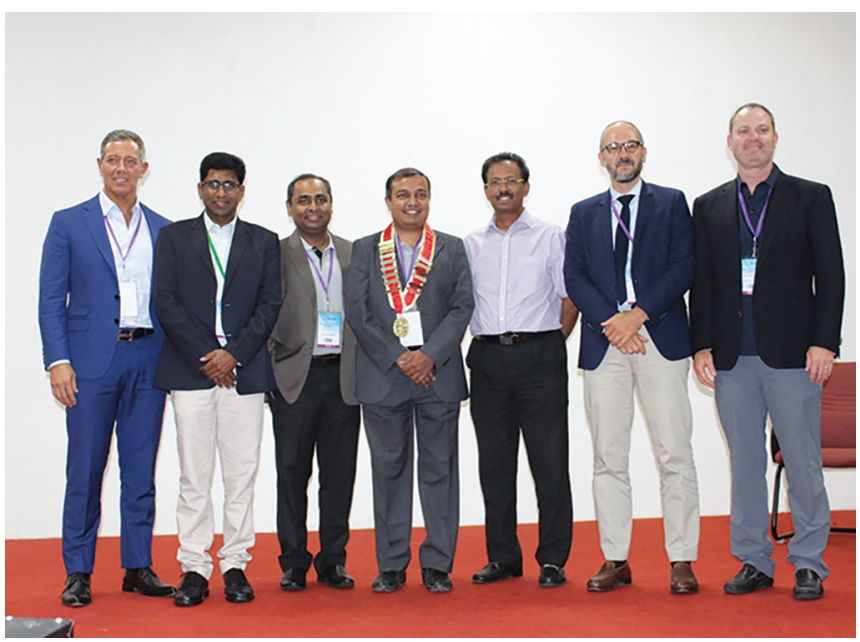

As the president of IFFAS, I finally get to understand that there is a huge amount of knowledge "hiding" in different languages or in local reports that may not be available for everyone to find. That is often the key to expanding educational horizons, and that is the aim of every good journal; many like this one begin with a small group of motivated people with an inherent interest in research. If they persist and work hard, then after some time they may succeed,

(0) The Author(s). 2020 Open Access This article is distributed under the terms of the Creative Commons Attribution 4.0 International License (https://creativecommons. org/licenses/by-nc/4.0/), which permits unrestricted use, distribution, and non-commercial reproduction in any medium, provided you give appropriate credit to the original author(s) and the source, provide a link to the Creative Commons license, and indicate if changes were made. The Creative Commons Public Domain Dedication waiver (http://creativecommons.org/publicdomain/zero/1.0/) applies to the data made available in this article, unless otherwise stated. 
as it has happened with this journal that has evolved from being the official voice of the Indian Foot and Ankle Society to being representative of many Asian Foot/Ankle societies.

Nevertheless, information is just the beginning of a good medical practice; all the rest, and the most important part of it, comes from being a human being truly interested in doing the best for his patients everyday. It has always amazed me that everyone who I admire as a doctor is at the same time a teacher, a researcher, and an amazing human being. This journal is the result of a group of people in Asia-Pacific who are sincerely committed to learn, teach, and investigate in a friendly feedback of updated knowledge.

Cristian Ortiz President IFFAS 2020-2023 